\title{
ANALISIS KETELITIAN AZIMUT PENGAMATAN MATAHARI DAN GLOBAL POSITIONING SYSTEM (GPS) \\ (Studi Kasus: Kampus ITS Sukolilo, Surabaya)
}

\author{
Yuwono ${ }^{1}$, Mohammad Luay Murtadlo ${ }^{2}$ \\ 1,2Teknik Geomatika, FTSLK-ITS Sukolilo, Surabaya 60111, Indonesia \\ Email: yuwono@geodesy.its.ac.id
}

\begin{abstract}
Determination of position, cannot ignore the name of the azimuth. In fact, the works relating to the ability of the geodetic disciplines require a determination of the azimuth. There are several ways to determine the azimuth, such as by observing celestial objects or with two measuring points of known coordinates. On the research methods used in for observation of the Solar using the altitude method, while for GPS observations using the differential method are tied at point CORS (continuously operating reference stations). The Altitude method was chosen because it has the advantage of his observations can be done in the morning and afternoon until dusk, while the differential method was chosen because it has the edge can eliminate or reduce the effects of some errors and bias (Abidin, 2007). From the results of calculation of azimuth values from three observations Sun gave a mean average precision by 4 minutes 48,5 seconds and with observations of the Global Positioning System (GPS) provide value average precision of 7,24 seconds against three azimuth values from two point Benchmark reference. GPS observation of azimuth values are more thorough than the Sun observations compared against the value of the azimuth from two point Benchmark reference.
\end{abstract}

Keywords: Azimuth, Altitude, Global Positioning System (GPS)

\begin{abstract}
Abstrak
Dalam melakukan penentuan posisi, selalu dibutuhkan azimut. Padahal, pekerjaan-pekerjaan yang menyangkut kemampuan disiplin ilmu geodesi membutuhkan suatu penentuan azimut. Prinsip dalam menentukan azimut ada beberapa cara, antara lain dengan cara melakukan pengamatan benda -benda langit atau dengan dua titik pengukuran yang sudah diketahui koordinatnya. Pada penelitian ini cara yang digunakan adalah dengan pengamatan matahari dan pengamatan dengan GPS (Global Positioning System). Untuk pengamatan matahari, metode yang digunakan adalah tinggi matahari, sedangkan untuk pengamatan dengan GPS digunakan metode diferensial yang diikatkan di titik CORS (Continuously Operating Reference Stations) ITS. Metode tinggi matahari dipilih karena memiliki keunggulan pengamatannya dapat dilakukan saat waktu pagi dan sore, sedangkan metode diferesial dipilih karena memiliki keunggulan dapat mengeliminir atau mereduksi pengaruh dari beberapa kesalahan dan bias (Abidin,2007). Dari hasil perhitungan tiga nilai azimut dari pengamatan matahari memberikan rata - rata ketelitian sebesar 4 menit 48,5 detik dan hasil dari pengamatan Global Positioning System (GPS) memberikan nilai rata - rata ketelitian sebesar 7,24 detik terhadap tiga nilai azimut dari dua titik BM referensi. Nilai azimut pengamatan GPS lebih teliti daripada pengamatan tinggi matahari yang dibandingkan terhadap nilai azimut dari dua titik BM referensi.
\end{abstract}

Kata Kunci: Azimut, Tinggi Matahari, Global Positioning System (GPS)

\section{PENDAHULUAN}

Dalam melakukan penentuan posisi, tidak dapat mengabaikan yang namanya azimut. Padahal, pekerjaan-pekerjaan yang menyangkut kemampuan disiplin ilmu geodesi membutuhkan suatu penentuan azimut (Yoel, 2009). Prinsip dalam menentukan azimut ada beberapa cara, antara lain dengan melakukan pengamatan benda-benda langit, yang umum dilakukan ialah terhadap matahari dan bintang. Selain itu dengan dua titik pengukuran yang sudah diketahui koordinatnya, dimana koordinat diperoleh dengan melakukan pengukuran menggunakan pengamatan Global Positioning System (GPS). Pada penelitian ini metode digunakan untuk pengamatan matahari menggunakan metode tinggi matahari, sedangkan untuk pengamatan GPS menggunakan metode diferensial yang diikatkan di titik CORS (Continuously Operating 
Reference Stations) ITS. Metode tinggi matahari dipilih karena memiliki keunggulan pengamatannya dapat dilakukan pagi dan sore. Dan metode diferesial dipilih karena memiliki keunggulan dapat mengeliminir atau mereduksi pengaruh dari beberapa kesalahan dan bias (Abidin,2007).

\section{METODOLOGI PENELITIAN}

Penelitian ini dilakukan di lokasi kampus Institut Teknologi Sepuluh Nopember (ITS) Sukolilo, Surabaya, Jawa Timur. Terdiri dari 4 titik BM yang masing - masing terletak di PRF Lab. Rekayasa Forensik, GPS 3 DESPRO, PPR Gedung Pusat Robotika dan PLE Lab. Energi, seperti terlihat pada Gambar 1

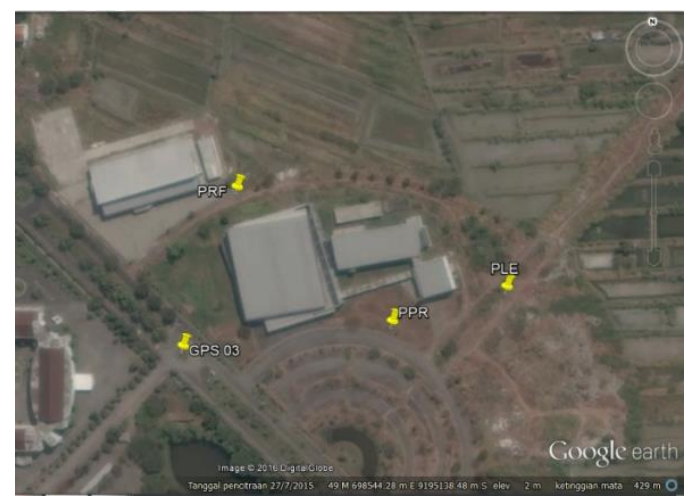

Gambar 1. Lokasi Penelitian

Data yang digunakan dalam penelitian ini yaitu data pengukuran sudut horisontal dan vertical matahari, nilai deklinasi matahari, koordinat BM referensi, dan tabel almanak matahari. Untuk peralatan yang digunakan dalam penelitian ini adalah: satu set Theodolit Dijital dan satu set alat GPS Secara garis besar tahapan dari pengolahan data yang dilakukan adalah seperti pada diagram alir pada Gambar 2.

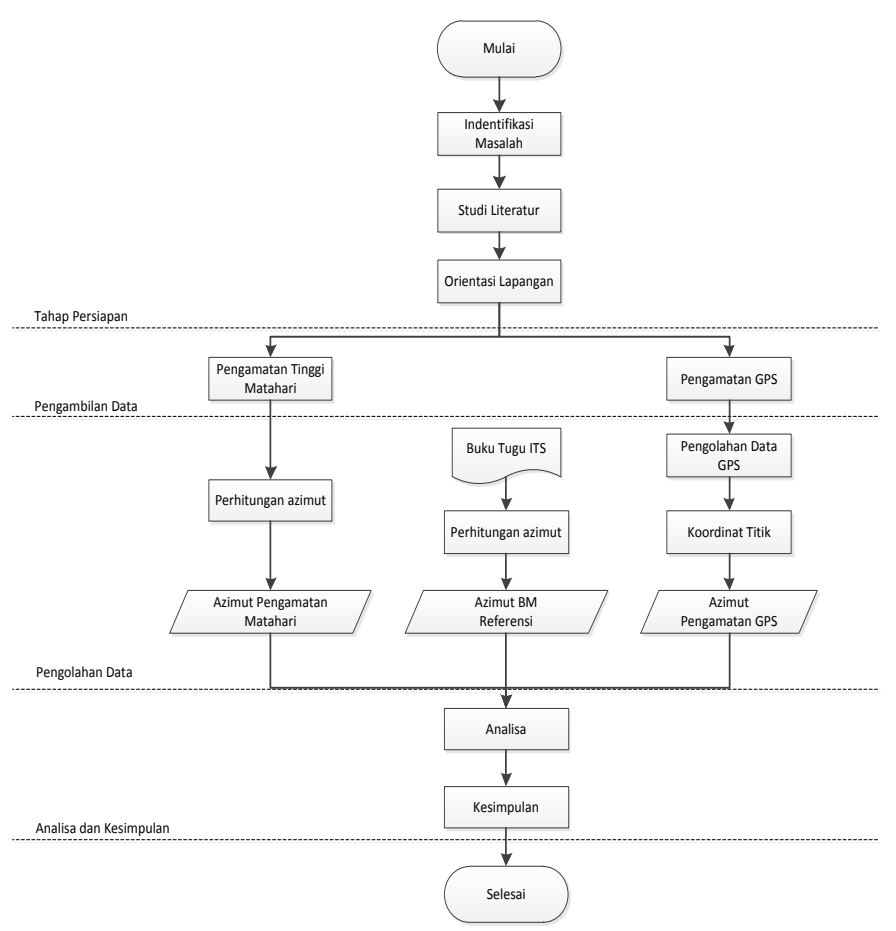

Gambar 2. Diagram Alir Tahapan Penelitian

\section{HASIL DAN PEMBAHASAN}

Hasil Perhitungan Azimut Pengamatan Matahari Perhitungan besarnya azimut pengamatan matahari dengan metode tinggi matahari dapat ditentukan dengan rumus (Kartawiharja, 1988) :

Dimana :

$$
\operatorname{Cos} \mathrm{AM}=\frac{\sin \delta-\sin \varphi \sin h}{\cos \varphi \cos h}
$$

AM = Azimut Matahari (dalam derajat)

$\mathrm{h} \quad=$ tinggi matahari saat pengamatan (dalam derajat)

$\delta \quad=$ deklinasi matahari (dalam derajat)

$\phi \quad=$ lintang pengamat(dalam derajat)

Dari rumus diatas didapatkan azimut pengamatan matahari, seperti terlihat pada Tabel 1, Tabel2, dan Tabel 3.

Tabel 1. Hasil perhitungan azimut dengan metode tinggi matahari PRF - GPSO3

\begin{tabular}{|c|c|c|c|c|}
\hline \multirow{2}{*}{ Pengamatan } & \multicolumn{3}{|c|}{ Azimut PRF - GPS03 } & \multirow{2}{*}{$\begin{array}{l}\text { Standar } \\
\text { Deviasi } \\
\text { (Detik) }\end{array}$} \\
\hline & Derajat & Menit & Detik & \\
\hline Sesi 1 & 197 & 52 & 56,28 & 23,95 \\
\hline Sesi 2 & 197 & 53 & 1,32 & 11,50 \\
\hline
\end{tabular}


Tabel 2. Hasil perhitungan azimut dengan metode tinggi matahari GPSO3 - PPR

\begin{tabular}{|c|c|c|c|c|}
\hline \multirow{2}{*}{ Pengamatan } & \multicolumn{3}{|c|}{ Azimut GPS03 - PPR } & \multirow{2}{*}{$\begin{array}{l}\text { Standar } \\
\text { Deviasi } \\
\text { (Detik) }\end{array}$} \\
\hline & Derajat & Menit & Detik & \\
\hline Sesi 1 & 86 & 35 & 2,94 & 18,88 \\
\hline Sesi 2 & 86 & 35 & 23,32 & 19,92 \\
\hline
\end{tabular}

Tabel 3. Hasil perhitungan azimut dengan metode tinggi matahari PPR - PLE

\begin{tabular}{lcccc}
\hline \multirow{2}{*}{ Pengamatan } & \multicolumn{3}{c}{ Azimut PPR - PLE } & Standar \\
& Derajat & Menit & Detik & Deviasi \\
(Detik)
\end{tabular}

\section{Hasil Perhitungan Azimut Pengamatan GPS}

Pada pengamatan (GPS), pengamatan dilakukan sebanyak 2 sesi dengan interval yang berbeda, antara lain pada interval 30 menit, 1 jam, dan 2 jam. Besarnya azimut dengan pengamatan GPS dapat ditentukan dari rumus vicenty (Vincenty, 1975). Dimana dalam rumus vicenty terdapat dua macam persoalan geodesi, yaitu Direct Problem dan Indirect Problem (Rainsford, 1955). Dari rumus vicenty didapatkan azimut pengamatan GPS sebagai berikut :

- Interval 30 menit

Tabel 4. Azimut Interval 30 menit Sesi 1

\begin{tabular}{lrrc}
\hline \multirow{2}{*}{ Nama } & \multicolumn{3}{c}{ Azimut } \\
& Derajat & Menit & Detik \\
\hline PRF-GPS03 & 197 & 54 & 55,30 \\
GPS03-PPR & 86 & 40 & 15,28 \\
PPR-PLE & 75 & 34 & 47,22 \\
\hline
\end{tabular}

Tabel 5. Azimut Interval 30 menit Sesi 2

\begin{tabular}{lrrc}
\hline \multirow{2}{*}{ Nama } & \multicolumn{3}{c}{ Azimut } \\
& Derajat & Menit & Detik \\
\hline PRF-GPS03 & 197 & 54 & 58,78 \\
GPS03-PPR & 86 & 40 & 15,42 \\
PPR-PLE & 75 & 34 & 49,02 \\
\hline
\end{tabular}

- Interval 1 jam

Tabel 6. Azimut Interval 1 Jam Sesi 1

\begin{tabular}{lrrc}
\hline \multirow{2}{*}{ Nama } & \multicolumn{3}{c}{ Azimut } \\
& Derajat & Menit & Detik \\
\hline PRF-GPS03 & 197 & 55 & 00,80 \\
GPS03-PPR & 86 & 40 & 16,48 \\
PPR-PLE & 75 & 34 & 44,10 \\
\hline
\end{tabular}

Tabel 7. Azimut Interval 1 jam Sesi 2

\begin{tabular}{lrrc}
\hline \multirow{2}{*}{ Nama } & \multicolumn{3}{c}{ Azimut } \\
& Derajat & Menit & Detik \\
\hline PRF-GPS03 & 197 & 55 & 00,01 \\
GPS03-PPR & 86 & 40 & 16,54 \\
PPR-PLE & 75 & 34 & 40,95 \\
\hline
\end{tabular}

- Interval 2 jam

Tabel 8. Azimut Interval 2 Jam Sesi 1

\begin{tabular}{lrrc}
\hline \multirow{2}{*}{ Nama } & \multicolumn{3}{c}{ Azimut } \\
& Derajat & Menit & Detik \\
\hline PRF-GPS03 & 197 & 55 & 00,80 \\
GPS03-PPR & 86 & 40 & 14,18 \\
PPR-PLE & 75 & 34 & 42,51 \\
\hline
\end{tabular}

Tabel 9. Azimut Interval 2 jam Sesi 2

\begin{tabular}{lrrc}
\hline \multirow{2}{*}{ Nama } & \multicolumn{3}{c}{ Azimut } \\
& Derajat & Menit & Detik \\
\hline PRF-GPS03 & 197 & 55 & 00,41 \\
GPS03-PPR & 86 & 40 & 14,21 \\
PPR-PLE & 75 & 34 & 42,79 \\
\hline
\end{tabular}

\section{Hasil Azimut BM Referensi}

Dalam buku tugu ITS, terdapat informasi koordinat BM referensi, yang kemudian dihitung azimutnya dari 2 titik BM referensi. Dimana azimut dari 2 titik BM referensi merupakan data yang dianggap benar. Berikut hasil perhitungan azimut dari 2 titik BM referensi dengan menggunakan rumus vicenty:

Tabel 10. Azimut BM Referensi

\begin{tabular}{lrrr}
\hline \multirow{2}{*}{ Nama } & \multicolumn{3}{c}{ Azimut } \\
& Derajat & Menit & Detik \\
\hline PRF-GPS03 & 197 & 56 & 30 \\
GPS03-PPR & 86 & 40 & 31.6 \\
PPR-PLE & 75 & 35 & 56.04 \\
\hline
\end{tabular}




\section{Perbandingan Hasil Koreksi Data}

Koreksi data yang dilakukan perbandingan adalah koreksi refraksi, dimana perbandingannya ditinjau dari suhu dan tekanan udara ketika pengamatan matahari dilakukan. Pada proses ini nilai refraksi menengah $(\mathrm{rm})$ pada rumus $r=r m . c p$. ct (Kartawiharja, 1988), dianggap sama, dimana nilai refraksi menengahnya sebesar 173,0 ".

\section{- Ditinjau Dari Suhu Yang Sama}

Tabel 11. Hasil Perhitungan Koreksi Refraksi

\begin{tabular}{|c|c|c|c|c|c|c|}
\hline \multicolumn{7}{|c|}{ Ditinjau Dari Suhu Yang Sama } \\
\hline Pengamatan & Sesi & Data $\mathrm{K}$ & Koreksi Refraksi & & & Selisih \\
\hline Azimut & Pengamatan & $\begin{array}{l}\text { Suhu } \\
\left({ }^{\circ} \mathrm{C}\right)\end{array}$ & $\begin{array}{c}\text { Tekanan Udara } \\
(\mathrm{mm} / \mathrm{Hg})\end{array}$ & Refraksi & Azimut & $\begin{array}{l}\text { Azimut } \\
\text { (Detik) }\end{array}$ \\
\hline PRF-GPS03 & 2 & \multirow{4}{*}{32} & 757,758 & $2^{\prime} 40,05$ " & $197^{\circ} 52^{\prime} 56,28^{\prime \prime}$ & 5,67 \\
\hline GPS03-PPR & 1 & & 757,339 & $2^{\prime} \quad 39,96=$ & $86^{\circ} 34^{\prime} 54,08^{\prime \prime}$ & 8,86 \\
\hline GPS03-PPR & 2 & & 757,472 & $2^{\prime} \quad 39,99 "$ & $86^{\circ} 35^{\prime} 18,46^{\prime \prime}$ & 4,86 \\
\hline PPR-PLE & 2 & & 757,764 & $2^{\prime} \quad 40,05=$ & $75^{\circ} 30^{\prime} 10,76^{\prime \prime}$ & 2,84 \\
\hline
\end{tabular}

Dari hasil perhitungan pada tabel 11 perbandingan koreksi refraksi ditinjau dari suhu yang sama dan tekanan udara yang berbeda, didapatkan koreksi refraksi yang sama sebesar 2'40,05" untuk pengamatan azimut dan sesi yang berbeda. Sedangkan untuk pengamatan azimut yang sama dengan sesi yang berbeda, didapatkan koreksi refraksi yang berbeda sebesar 2'39,96" dan 2'39,99'.

Pada tabel 11 perhitungan azimut dan selisih azimut didapatkan dari azimut hasil perhitungan pengamatan yang terbaik dan koreksi refraksi ditinjau dari suhu yang sama dengan dibandingkan pada hasil perhitungan azimut metode tinggi matahari tiap sesinya.

- Ditinjau Dari Tekanan Yang Sama

Tabel 12. Hasil Perhitungan Koreksi Refraksi Ditinjau Dari Tekanan Udara Yang Sama

\begin{tabular}{|c|c|c|c|c|c|c|}
\hline \multirow{2}{*}{$\begin{array}{c}\text { Pengamatan } \\
\text { Azimut }\end{array}$} & Komb & \multicolumn{2}{|c|}{ Data Koreksi Refraksi } & \multirow{2}{*}{$\begin{array}{l}\text { Koreksi } \\
\text { Refraksi }\end{array}$} & \multirow{2}{*}{$\begin{array}{c}\text { Perhitungan } \\
\text { Azimut }\end{array}$} & \multirow{2}{*}{$\begin{array}{l}\text { Selisih } \\
\text { Azimut }\end{array}$} \\
\hline & & $\begin{array}{r}\text { Suhu } \\
\left({ }^{\circ} \mathrm{C}\right)\end{array}$ & & & & \\
\hline$\overline{\mathrm{PSO}}$ & 7 & 32 & & $39,96 "$ & $86^{\circ} 35^{\prime} 18,46^{\prime \prime}$ & 4,86 \\
\hline PPR-P & 2 & 30 & & $2^{\prime} 29,93$ " & $75^{\circ} 29^{\prime} 58,92^{\prime \prime}$ & 1,84 \\
\hline
\end{tabular}

Dari hasil perhitungan pada tabel 12 perbandingan koreksi refraksi ditinjau dari tekanan udara yang sama dan suhu yang berbeda, didapatkan koreksi refraksi yang berbeda sebesar 2'39,96" dan 2'29,93" untuk pengamatan azimut dan sesi yang sama.
Pada tabel 12 perhitungan azimut dan selisih azimut didapatkan dari azimut hasil perhitungan pengamatan yang terbaik dan koreksi refraksi ditinjau dari suhu yang sama dengan dibandingkan pada hasil perhitungan azimut metode tinggi matahari tiap sesinya.

\section{Analisa Ketelitian Nilai Azimut Melalui Pengamatan Matahari}

Hasil dari perhitungan melalui pengamatan matahari yang dibandingkan dengan azimut BM Referensi. Hasil perhitungan ketelitiannya dapat dilihat pada tabel 13.

Tabel 13. Hasil Perbandingan Nilai Azimut Melalui Pengamatan Matahari

\begin{tabular}{ccccc}
\hline $\begin{array}{c}\text { Pengamatan } \\
\text { Azimut }\end{array}$ & Derajat & $\begin{array}{c}\text { Azimut } \\
\text { Menit }\end{array}$ & Detik & $\begin{array}{c}\text { RMSE } \\
\text { (Detik) }\end{array}$ \\
\hline PRF-GPS03 & 197 & 52 & 56,28 & 52,32 \\
& 197 & 53 & 1,32 & \\
GPS03-PPR & 86 & 35 & 2,94 & 425,99 \\
& 86 & 35 & 23,32 & \\
PPR-PLE & 75 & 30 & 7,15 & 387,2 \\
& 75 & 30 & 10,76 & \\
\hline
\end{tabular}

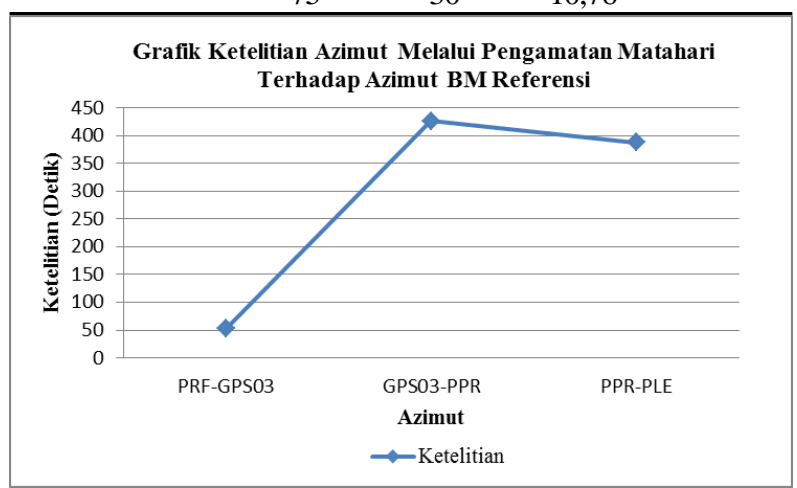

Gambar 3. Grafik Ketelitian Azimut Melalui Pengamatan Matahari Terhadap BM Referensi

Gambar 3. menyatakan hubungan nilai ketelitian azimut melalui pengamatan matahari terhadap azimut BM referensi yang diperoleh pada tabel 13 . Dari gambar dapat diambil hasil ketelitian pada azimut PRF-GPSO3 adalah 52,32", pada azimut GPS03-PPR adalah 425,99, dan pada azimut PPRPLE adalah 387,2.

\section{Analisa Ketelitian Nilai Azimut Melalui Pengamatan GPS}

Hasil dari perhitungan melalui pengamatan GPS yang dibandingkan dengan azimut BM Referensi. Hasil perhitungan ketelitian untuk azimut PRF- 
GPS03, azimut GPS03-PPR, dan azimut PPR-PLE dapat dilihat dalam tabel 14, 15, dan 16.

Tabel 14. Hasil Perbandingan Nilai Azimut PRFGPS03 Melalui Pengamatan GPS

\begin{tabular}{ccccc}
\hline $\begin{array}{c}\text { Interval } \\
\text { Pengamatan }\end{array}$ & Derajat & $\begin{array}{c}\text { Azimut } \\
\text { Menit }\end{array}$ & Detik & $\begin{array}{c}\text { RMSE } \\
\text { (Detik) }\end{array}$ \\
\hline \multirow{2}{*}{30 Menit } & 197 & 54 & 55,3 & 5,63 \\
& 197 & 54 & 58,78 & \\
\multirow{2}{*}{60 Menit } & 197 & 55 & 0,8 & 0,64 \\
& 197 & 55 & 0,01 & \\
\multirow{2}{*}{120 Menit } & 197 & 55 & 0,8 & 0,28 \\
& 197 & 55 & 0,41 & \\
\hline
\end{tabular}

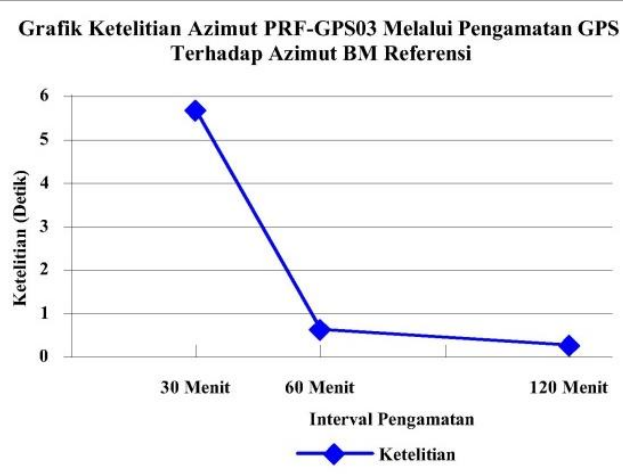

Gambar 4. Grafik Ketelitian Azimut PRF-GPSO3 Terhadap BM Referensi

Gambar 4. menyatakan hubungan nilai ketelitian azimut melalui pengamatan GPS terhadap azimut BM referensi yang diperoleh pada tabel 14. Dari gambar dapat diambil hasil ketelitian pada interval waktu 30 menit adalah 5,63", pada interval waktu 1 jam adalah 0,64", dan pada interval waktu 2 jam adalah $0,28^{\prime \prime}$.

Tabel 15. Hasil Perbandingan Nilai Azimut GPSO3PPR Melalui Pengamatan GPS

\begin{tabular}{ccccc}
\hline $\begin{array}{c}\text { Interval } \\
\text { Pengamatan }\end{array}$ & Derajat & $\begin{array}{c}\text { Azimut } \\
\text { Menit }\end{array}$ & Detik & $\begin{array}{c}\text { RMSE } \\
\text { (Detik) }\end{array}$ \\
\hline \multirow{2}{*}{ 30 Menit } & 86 & 40 & 15,3 & 3,3 \\
& 86 & 40 & 15,42 & \\
\multirow{2}{*}{ 60 Menit } & 86 & 40 & 16,48 & 1,67 \\
& 86 & 40 & 16,54 & \\
120 Menit & 86 & 40 & 14,18 & 0,03 \\
& 86 & 40 & 14,21 & \\
\hline
\end{tabular}

Grafik Ketelitian Azimut GPS03-PPR Melalui Pengamatan GPS Terhadap Azimut BM Referensi

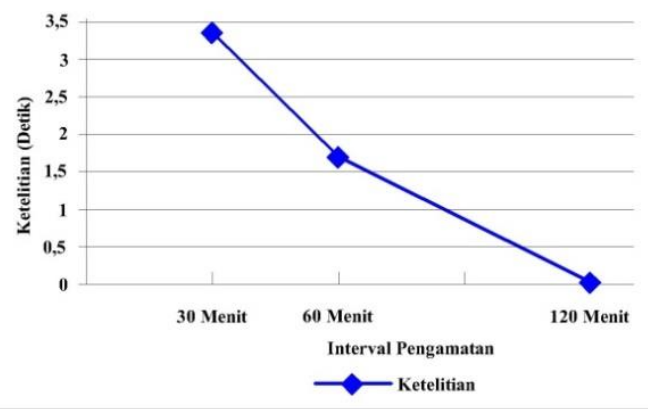

Gambar 5. Grafik Ketelitian Azimut GPS03-PPR Terhadap BM Referensi

Gambar 5. menyatakan hubungan nilai ketelitian azimut melalui pengamatan GPS terhadap azimut BM referensi yang diperoleh pada tabel 15. Dari gambar dapat diambil hasil ketelitian pada interval waktu 30 menit adalah 1,67", dalam interval waktu 1 jam adalah 3,3", dan pada interval waktu 2 jam adalah 0,03 ".

Tabel 16. Hasil Perbandingan Nilai Azimut PPR-PLE Melalui Pengamatan GPS

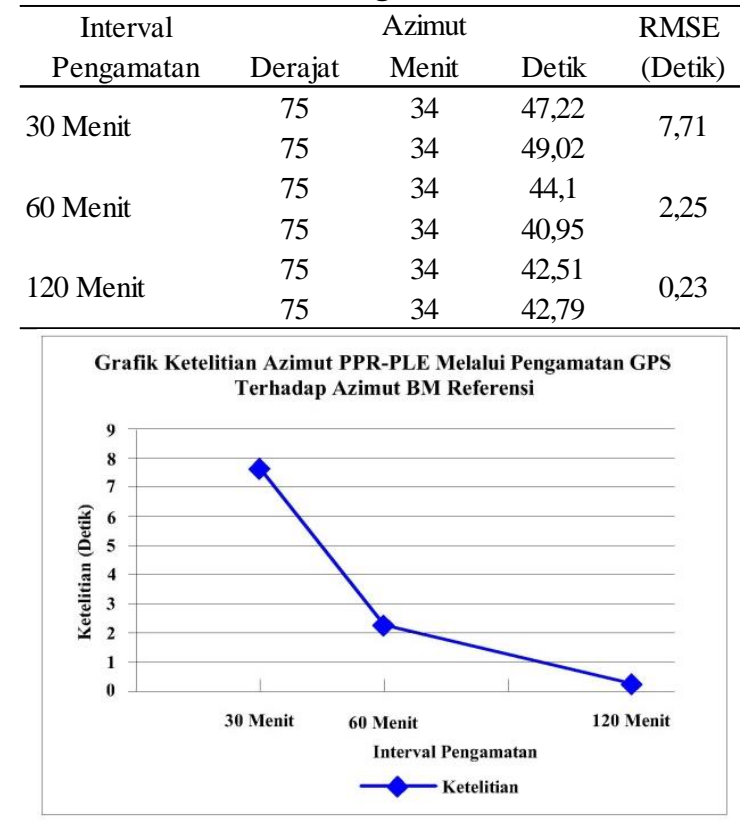

Gambar 6. Grafik Ketelitian Azimut PPR-PLE Terhadap BM Referensi

Gambar 6. menyatakan hubungan nilai ketelitian azimut melalui pengamatan GPS terhadap azimut BM referensi yang diperoleh pada tabel 16. Dari gambar dapat diambil hasil ketelitian pada interval waktu 30 menit adalah 7,71", dalam interval 
waktu 1 jam adalah 2,25", dan pada interval waktu 2 jam adalah 0,23".

\section{Analisa Ketelitian Nilai Azimut Interval Per 10 Menit Tiap Metode}

Hasil dari perhitungan ketelitian azimut dengan interval 10 menit melalui pengamatan matahari dan pengamatan GPS yang dibandingkan dengan azimut BM Referensi. Hasil perhitungan ketelitian untuk azimut PRF-GPS03, azimut GPS03-PPR, dan azimut PPR-PLE dapat dilihat dalam tabel 17, 18, dan 19.

Tabel 17. Hasil Perbandingan Nilai Azimut PRFGPS03 Interval 10 Menit

\begin{tabular}{ccccc}
\hline $\begin{array}{c}\text { Metode } \\
\text { Pengamatan }\end{array}$ & Derajat & $\begin{array}{c}\text { Azimut } \\
\text { Menit }\end{array}$ & Detik & $\begin{array}{c}\text { RMSE } \\
\text { (Detik) }\end{array}$ \\
\hline \multirow{2}{*}{ Tinggi Matahari } & 197 & 50 & 34,08 & 289,70 \\
& 197 & 53 & 7,44 & \\
GPS & 197 & 54 & 52,50 & \multirow{2}{*}{11,78} \\
& 197 & 54 & 52,08 & \\
\hline
\end{tabular}

Tabel 18. Hasil Perbandingan Nilai Azimut GPSO3PPR Interval 10 Menit

\begin{tabular}{ccccc}
\hline $\begin{array}{c}\text { Metode } \\
\text { Pengamatan }\end{array}$ & Derajat & $\begin{array}{c}\text { Azimut } \\
\text { Menit }\end{array}$ & Detik & $\begin{array}{c}\text { RMSE } \\
\text { (Detik) }\end{array}$ \\
\hline \multirow{2}{*}{ Tinggi Matahari } & 86 & 35 & 1,03 & \multirow{2}{*}{429,84} \\
& 86 & 35 & 19.72 & \\
GPS & 86 & 40 & 13,30 & \multirow{2}{*}{2,58} \\
& 86 & 40 & 11,75 & \\
\hline
\end{tabular}

Tabel 19. Hasil Perbandingan Nilai Azimut PPR-PLE Interval 10 Menit

\begin{tabular}{ccccc}
\hline $\begin{array}{c}\text { Metode } \\
\text { Pengamatan }\end{array}$ & Derajat & $\begin{array}{c}\text { Azimut } \\
\text { Menit }\end{array}$ & Detik & $\begin{array}{c}\text { RMSE } \\
\text { (Detik) }\end{array}$ \\
\hline \multirow{2}{*}{ Tinggi Matahari } & 75 & 30 & 8.53 & 2 \\
& 75 & 30 & 16.67 & \\
\multirow{2}{*}{ GPS } & 75 & 34 & 39.68 & \multirow{2}{*}{14,57} \\
& 75 & 34 & 49,20 & \\
\hline
\end{tabular}

Pada interval 20 menit, hasil perhitungan ketelitian untuk azimut PRF-GPS03, azimut GPSO3PPR, dan azimut PPR-PLE dapat dilihat dalam tabel 20, 21, dan 22
Tabel 20. Hasil Perbandingan Nilai Azimut PRFGPS03 Interval 20 Menit

\begin{tabular}{ccccc}
\hline $\begin{array}{c}\text { Metode } \\
\text { Pengamatan }\end{array}$ & Derajat & $\begin{array}{c}\text { Azimut } \\
\text { Menit }\end{array}$ & Detik & $\begin{array}{c}\text { RMSE } \\
\text { (Detik) }\end{array}$ \\
\hline \multirow{2}{*}{ Tinggi Matahari } & 197 & 50 & 34,08 & 2 \\
& 197 & 53 & 7,44 & \\
\multirow{2}{*}{ GPS } & 197 & 54 & 52,50 & \multirow{2}{*}{11,78} \\
& 197 & 54 & 52,08 & \\
\hline
\end{tabular}

Tabel 21. Hasil Perbandingan Nilai Azimut GPSO3PPR Interval 20 Menit

\begin{tabular}{ccccc}
\hline $\begin{array}{c}\text { Metode } \\
\text { Pengamatan }\end{array}$ & Derajat & $\begin{array}{c}\text { Azimut } \\
\text { Menit }\end{array}$ & Detik & $\begin{array}{c}\text { RMSE } \\
\text { (Detik) }\end{array}$ \\
\hline \multirow{2}{*}{ Tinggi Matahari } & 86 & 35 & 1,03 & \multirow{2}{*}{429,84} \\
& 86 & 35 & 19.72 & \\
GPS & 86 & 40 & 20,82 & \multirow{2}{*}{6,68} \\
\hline
\end{tabular}

Tabel 22. Hasil Perbandingan Nilai Azimut PPR-PLE Interval 10 Menit

\begin{tabular}{ccccc}
\hline $\begin{array}{c}\text { Metode } \\
\text { Pengamatan }\end{array}$ & Derajat & $\begin{array}{c}\text { Azimut } \\
\text { Menit }\end{array}$ & Detik & $\begin{array}{c}\text { RMSE } \\
\text { (Detik) }\end{array}$ \\
\hline Tinggi Matahari & 75 & 30 & 8.53 & 3282,07 \\
& 75 & 30 & 16.67 & \\
GPS & 75 & 34 & 29,68 & \multirow{2}{*}{14,57} \\
\hline
\end{tabular}

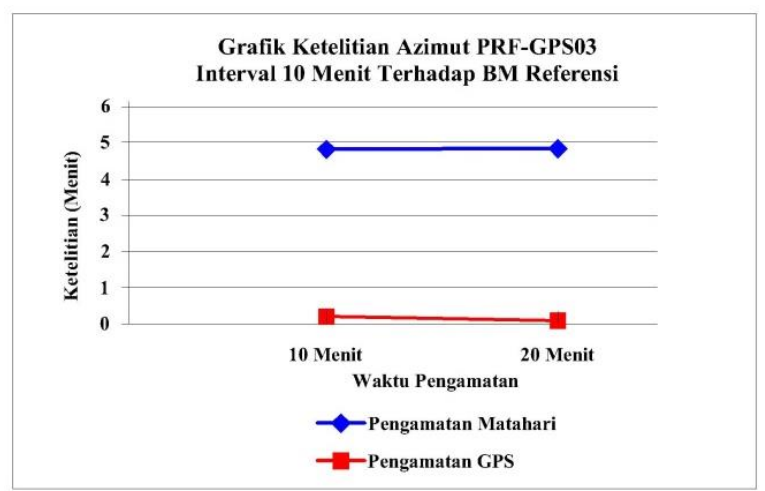

Gambar 7. Grafik Keteltian Nilai Azimut PRFGPS03 Interval Per 10 Menit Tiap Metode Tehadap Azimut BM Referensi

Gambar 7. menyatakan nilai ketelitian azimut dengan interval per 10 menit melalui pengamatan matahari dan pengamatan GPS yang dibandingkan dengan azimut BM Referensi, hasil pembahasan dari tabel 17 untuk pengamatan dengan interval 10 menit dan tabel 20 untuk pengamatan dengan interval 20 menit. 


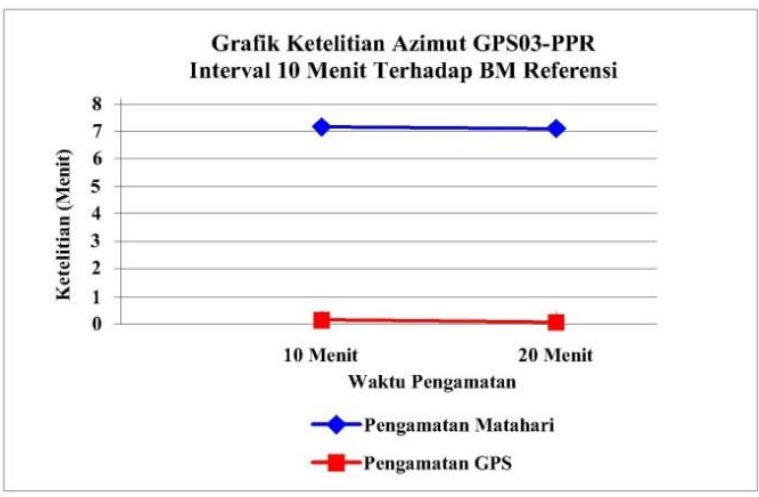

Gambar 8. Grafik Keteltian Nilai Azimut GPS03PPR Interval Per 10 Menit Tiap Metode Tehadap Azimut BM Referensi

Gambar 8. menyatakan nilai ketelitian azimut dengan interval per 10 menit melalui pengamatan matahari dan pengamatan GPS yang dibandingkan dengan azimut BM Referensi, hasil pembahasan dari tabel 18 untuk pengamatan dengan interval 10 menit dan tabel 19 untuk pengamatan dengan interval 20 menit.

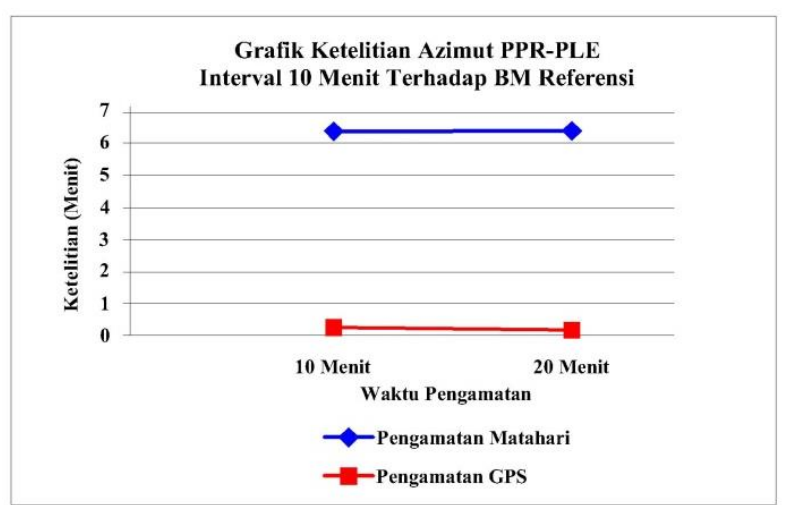

Gambar 9. Grafik Keteltian Nilai Azimut PPR-PLE Interval Per 10 Menit Tiap Metode Tehadap

Azimut BM Referensi

Gambar 9. menyatakan nilai ketelitian azimut dengan interval per 10 menit melalui pengamatan matahari dan pengamatan GPS yang dibandingkan dengan azimut BM Referensi, hasil pembahasan dari tabel 19 untuk pengamatan dengan interval 10 menit dan tabel 20 untuk pengamatan dengan interval 20 menit.

\section{Jarak Penyimpangan Azimut Tiap Metode Terhadap Azimut BM Referensi}

Akibat adanya selisih antara azimut tiap metode tehadap azimut BM referensi yang dianggap benar, menyebabkan terjadinya penyimpangan pula pada perpanjangan arah orientasi terhadap titik acuan BM referensi. Oleh karena itu, perlu dilakukan perhitungan lebih lanjut untuk mengetahui jarak penyimpangan tersebut.

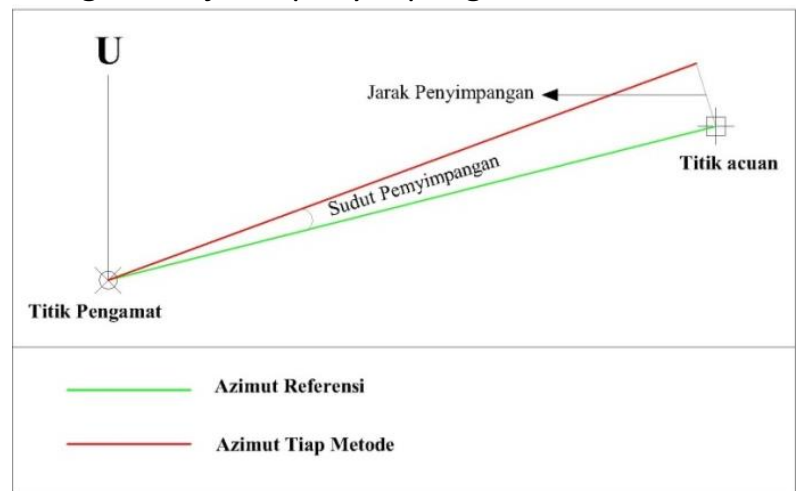

Gambar 10. Ilustrasi Jarak Penyimpangan Azimut Tiap Metode Terhadap Azimut BM Referensi Pada perhitungan untuk mengetahui besar jarak penyimpangan tersebut, dilakukan perhitungan yang dimana jarak dari tempat pengamat ke titik acuan dianggap memiliki jarak sepanjang $1 \mathrm{~km}$, dan untuk sudut penyimpangannya didapatkan dari ketelitian azimut tiap metode pengamatan terhadap azimut BM referensi.

Tabel 23. Jarak Penyimpangan Azimut PRF-GPSO3 Terhadap Azimut BM Referensi

\begin{tabular}{lcc}
\hline $\begin{array}{c}\text { Metode } \\
\text { Pengamatan }\end{array}$ & $\begin{array}{c}\text { Ketelitian Azimut } \\
\text { (Detik) }\end{array}$ & $\begin{array}{c}\text { Penyimpangan } \\
\text { Jarak (m) }\end{array}$ \\
\hline Tinggi Matahari & 52,32 & 0,254 \\
GPS 30 Menit & 5,63 & 0,027 \\
GPS 1 Jam & 0,64 & 0,003 \\
GPS 2 Jam & 0,28 & 0,001 \\
\hline
\end{tabular}

Tabel 24. Jarak Penyimpangan Azimut GPS03-PPR Terhadap Titik Acuan BM Referensi

\begin{tabular}{lcc}
\hline $\begin{array}{c}\text { Metode } \\
\text { Pengamatan }\end{array}$ & $\begin{array}{c}\text { Ketelitian Azimut } \\
(\text { Detik })\end{array}$ & $\begin{array}{c}\text { Jarak Penyimpangan } \\
(\mathrm{m})\end{array}$ \\
\hline Tinggi Matahari & 425,99 & 2,065 \\
GPS 30 Menit & 3,3 & 0,016 \\
GPS 1 Jam & 1,67 & 0,008 \\
GPS 2 Jam & 0,03 & 0 \\
\hline
\end{tabular}

Tabel 25. Jarak Penyimpangan Azimut PPR-PLE Terhadap Titik Acuan BM Referensi 


\begin{tabular}{lcc}
\hline $\begin{array}{c}\text { Metode } \\
\text { Pengamatan }\end{array}$ & $\begin{array}{c}\text { Ketelitian Azimut } \\
\text { (Detik) }\end{array}$ & $\begin{array}{c}\text { Jarak Penyimpangan } \\
(\mathrm{m})\end{array}$ \\
\hline Tinggi Matahari & 425,99 & 2,065 \\
GPS 30 Menit & 3,3 & 0,016 \\
GPS 1 Jam & 1,67 & 0,008 \\
GPS 2 Jam & 0,03 & 0 \\
\hline
\end{tabular}

Dari hasil perhitungan jarak penyimpangan azimut tiap metode terhadap azimut BM referensi pada tabel 23, 24, dan 25. Dapat disimpulkan bahwa semakin kecil nilai ketelitian azimut dari sebuah pengamatan terhadap azimut BM referensi, semakin kecil juga jarak penyimpangannya. Sedangkan semakin besar nilai ketelitian azimut dari sebuah pengamatan, semakin besar juga jarak penyimpangannya dari azimut BM referensi.

\section{PENUTUP}

Dalam penelitian ini, BM referensi didapatkan dari buku tugu ITS, sehingga kesimpulan yang dapat diambil sebagai berikut :

1. Nilai ketelitian pengamatan azimut dengan GPS untuk interval pengamatan 30 menit memiliki nilai rata - rata sebesar 5,55 detik, untuk interval pengamatan 1 jam memiliki nilai rata - rata sebesar 1,52 detik, dan untuk interval pengamatan 2 jam memiliki nilai rata - rata sebesar 0,18 detik terhadap nilai azimut dari 2 titik BM referensi, sedangkan dengan menggunakan metode matahari yang terendah 11,5 detik dan yang tertinggi 26,3 detik.

2. Ketelitian nilai azimut dari pengamatan matahari dengan menggunakan alat Electronic Digital Theodolite memiliki nilai sebesar 52,32 detik untuk azimut PRF-GPSO3, untuk azimut GPS03-PPR memiliki nilai sebesar 7 menit 5,99 detik, dan untuk azimut PPR-PLE memiliki nilai sebesar 6 menit 27,2 detik terhadap nilai azimut dari 2 titik BM referensi.

3. Ketelitian nilai azimut dari pengamatan GPS memiliki nilai sebesar 2,18 detik untuk azimut PRF-GPS03, untuk azimut GPS03-PPR memiliki nilai sebesar 1,67 detik, dan untuk azimut PPR-PLE memiliki nilai sebesar 3,39 detik terhadap nilai azimut dari 2 titik BM referensi.

\section{Saran}

Beberapa saran yang dapat penulis sampaikan untuk penelitian yang lebih lanjut adalah :

1. Untuk penelitian salanjutnya, pengamatan metode tinggi matahari dilakukan pengamatan dengan waktu yang lebih lama dan dilengkapi dengan kronometer (jam teliti) yang telah terkalibrasi untuk melengkapi hasil penelitian.

2. Untuk penelitian salanjutnya, lokasi pengamatan diusahakan di lokasi yang terbuka untuk memperkecil kesalahan sistematis dari masing - masing metode pengamatan azimut.

3. Untuk penelitian salanjutnya, penelitian ini akan lebih baik apabila menggunakan tabel almanak matahari yang terbaru.

\section{UCAPAN TERIMA KASIH}

Ucapan terima kasih kepada Dinas Pengelola Bangunan dan Tanah Kota Surabaya yang telah menyediakan data untuk pembuatan karya tulis ini.

\section{DAFTAR PUSTAKA}

Prawiro, Yoel., Taufik, M., dan Muhamdi, Mansur., "Penentuan Azimut Pada Pengamatan Bintang Dengan Metode Diurnal Circle".

Abidin, Hasanuddin. 2007. Penentuan Posisi dengan GPS dan Aplikasinya. Jakarta: Pradnya Paramita.

Vincenty, T. (1975). Direct and Inverse Solutions of Geodesics on The Ellipsoid with Application of Nested Equations. Survey Review XXII. 176.

Rainsford, H. (1955). Long Geodesics on the Ellipsoid. Bulletin Geodesique, 12-21.

Kartawiharja, Ir. S. Basuki. 1988. Penentuan Azimuth Dengan Pengamatan Matahari. Kanisius. Jogjakarta. 